\title{
Good Practices and Learning Benefits in the Implementation of Total Quality Management (TQM) in Msmes
}

\author{
H Halpiah* \\ Accounting Study Program \\ Al-Azhar Islamic University \\ Mataram, Indonesia \\ pettamaccahaya@gmail.com
}

\author{
Hery Astika Putra \\ Accounting Study Program \\ Al-Azhar Islamic University \\ Mataram, Indonesia \\ heryptra@gmail.com
}

\author{
Baiq Rizka Milania Ulfah \\ Economic Development Study Program \\ Al-Azhar Islamic University \\ Mataram, Indonesia \\ rizkabaiq@gmail.com
}

\begin{abstract}
This research was conducted based on the various problems that occur in bread entrepreneurs who are the members of "Babakan MSMEs Village", such as access to capital, unfair business competition, financial reports, slow adaptation to technological changes, and purchase of raw materials that always use a debt system which causes the business process to be hard developed. Therefore, researchers are interested in conducting this research by using qualitative research paradigm cross-case analysis. The purpose of this research is to compare the bread entrepreneurs who have developed to accept technological changes and willing to implement TQM in their business activities and bread entrepreneurs who still implement the traditional system with various problems that occur, because of 26 bread entrepreneurs who are members of the Babakan MSMEs Village bread, only one of bread entrepreneur who tried to implement TQM and within two years was able to build a modern bakery market segments from various backgrounds and have opened bread outlets in Mataram besides in Babakan village. The results showed that the bread entrepreneurs who started trying to implement TQM in their business activities gain the perceived good practice, namely prioritizing the quality of bread with product differentiation is learning that focuses on customer satisfaction to gains profit. Meanwhile, bread entrepreneurs who have not tried to implement the TQM in their business activities are only for survival, not for business development and business expansion with the unfair competition due to producing the same type of bread at uncompetitive prices.
\end{abstract}

\section{Keywords-Good Practice, TQM, MSMEs}

\section{INTRODUCTION}

In the current era of economic globalization, business competition has become increasingly competitive that makes business entrepreneurs must innovate and move from traditional management systems to modern management systems to adapt to the times and consumer needs. This does not only implement to entrepreneurs who are successful in managing companies with turnover of tens or even billions of rupiah per month but also implement to Micro, Small, and Medium Enterprises (MSMEs). This is in accordance with the definition of MSMEs referring to Law No. 20 of 2008 concerning Micro, Small and Medium Enterprises. MSMEs is individual-owned businesses or productive individual business entities that start a business from the intention to increase income through small businesses in order to be able to meet the needs of family life with the hope that it will continue to grow. The thing that makes small and medium micro businesses able to survive from the business' competition is a significant increase in turnover despite a lot of the same products on the market. Therefore, the MSMEs entrepreneurs in Indonesia are no exception to the Babakan MSMEs entrepreneurs, totaling 26 entrepreneurs who have been running their business from generation to generation since the 1980s who are in Babakan sub-district, Mataram city, West Nusa Tenggara province and is still operating until now, but the business is not so developed with the various problems it faces such as access to capital, unfair business competition, financial reports, slow adaptation to technological changes, and the purchase of raw materials always with debt system which causes the business process to be hard developed, limited access to marketing, simple and obsolete production for the equipment, unclear organizational structures and management hierarchies. This happens because of the MSMEs entrepreneurs are still applying the traditional management system in running their business, just to continue the business of parents without the development of good business management because for this MSMEs entrepreneurs being able to survive and be able to pay debts and meet the necessities of life are enough for them.

The research problems that are findings in this study can be resolved if MSMEs entrepreneurs move from traditional management to modern management by implementing Total Quality Management (TQM) in their business practices because the application of TQM is beneficial in increasing profits and competitiveness in the future by improving the quality of the products. In accordance with the definition of TQM by Gaspersz [1] that TQM is a way of continuously improving performance (continuous performance improvement) at each level of operation or process in every functional area of an organization using all available human resources and capital. From this definition, it means that in running a business, the most important thing is to always improve the quality of all aspects both in terms of products, services and marketing access so that business actors are able to retain and attract new consumers in their business environment. It can be implemented perfectly when MSMEs entrepreneurs pay attention to the implementation of ten characteristics in TQM according to Tjiptono \& Diana [2], namely: 1. Focus on customers, 2. Have a high obsession with quality, 3. Use a scientific approach in decision making and problem solving, 4. Have a long-term commitment, 5. Teamwork is needed, 6. Improving the process on continuously, 7. Organizing education and training, 8. Providing controlled burdens, 9. Having a unity 
of purpose, 10. The involvement and empowerment of employees.

The TQM system serves to complement the quality requirements demanded by consumers in achieving the desired quality from the producer. This is in line with the results of Akhyar's research, [3] which states that TQM requires total commitment from management as a company leader where this commitment must be distributed to all employees and at all levels or departments in the organization. TQM is a system approach to integrate all functions and processes in an organization in order to achieve improvement of the quality of goods and services with the aim of achieving consumer satisfaction [4]. Total Quality Management is an approach that allows producers to work hard to create an environment for workers to make products perfectly without defects [5]. Meanwhile, according to [6] said that TQM is a method with the culture, attitude and organizational structure of a company that tries to provide customers with products and services that complement or exceed their needs by involving management and all employees in continuous improvement of products and services produced by reducing losses due to wasteful and defective practices. In line with this opinion Goetsch\& Davis, [7] stated that TQM is an approach to running a business that maximizes the competition for an organization through continuous improvement of the quality of products, services, people, processes, and the environment. According to Krajewski et al., [8], TQM is a new paradigm in running a business that makes an effort to maximize organizational competitiveness through focus on customer satisfaction, involvement of all employees, and continuous improvement of service quality, people, processes and organizational environment. From these definitions, it can be concluded that Total Quality Management (TQM) is a system or concept of a company or organization that improve the quality continually in running the business towards a competitive advantage.

From the 26 MSMEs bread entrepreneurs in Babakan village, 25 bread entrepreneurs still use the traditional management system who are more concerned with the production of bread without paying attention to quality so that the amount of bread produced each day tends to decrease and the target market is traditional markets in the districts of East Lombok, Central Lombok, West Lombok, North Lombok, and some in traditional markets in Mataram city. All types of bread are produced at the same price, which is Rp. 800 to Rp. 900.-, then the profits are still shared with the wholesalers because the MSMEs bread entrepreneurs do not sell directly to the consumer so this is a factor in the occurrence of unfair business competition. Based on this background, the problems that will be discussed in the research are how and what kind of good practice and the benefits of learning if Total Quality Management (TQM) is applied to MSMEs bread entrepreneurs in business operational activities that are being carried out.

\section{METHOD}

This study uses a qualitative paradigm which can be interpreted as an investigative process in which researchers slowly interpret a social phenomenon by distinguishing, comparing, duplicating, cataloging, and classifying research objects [9].The data collection through observation, interviews, use of documents as data collection based on findings in the field during the research conducted. Meanwhile, the approach in this study uses Cross Case Analysis which aims to increase the external validation of a case by observing various entrepreneurs in various situations because each individual has a diverse background and life history and affects by their development [10]. In this case, the researcher compares the cases or problems faced by MSMEs bread entrepreneurs who still use traditional management based on feelings in running their business and MSMEs bread entrepreneurs who have tried to implement Total Quality Management. The informants in this study were 26 MSMEs bread entrepreneurs in the Babakan Village, Sandubaya District, Mataram City, West Nusa Tenggara Province.

\section{RESULTS AND DISCUSSION}

\section{Cross Case Analysis}

In discussion on Cross Case Analysis, the researcher will compare the findings based on the problems or cases faced by MSMEsentrepreneurs.

Case 1: problems faced by MSMEs bread entrepreneurs with traditional management systems.

1. The MSMEs bread entrepreneurs run their business based on feeling, just continuing their parents' business from generation to generation without product innovation and not using business strategies;

2. Operating theMSMEs with an old business strategy so that it is difficult to develop due to unfair competition;

3. Having difficulty in accessing the capital;

4. Slow adaptation to technological changes;

5. Marketing has not implemented marketing digitization;

6. Bookkeeping still uses a drawer system without making financial reports;

7. The raw material of bread transactions on credit;

8. Production equipment is very outdated;

9. In production activities do not prioritize quality;

10. Always feel in a safe and comfortable zone;

11. Running a business without an organizational structure and management hierarchy.

Case 2: problems faced by MSMEs bread entrepreneurs who have tried to implement TQM

1. Digitalization of marketing is still not optimal;

2. The making of financial reports has not been based on Financial Accounting Standards for Micro, Small and Medium Enterprises (SAK-EMKM);

3. Employee empowerment has not been maximal.

Case solving 1: In the current industrial 4.0 era, the MSMEs entrepreneurs will face free market and intense competition in the same market segment so they must carry out productive and efficient production activities, and produce quality products so that they can be sold nationally and globally in the future. In order for this to be carried out, the government, academics and MSMEs Economics practitioners work together to go directly to meet MSMEs entrepreneurs to conduct socialization and provide an understanding of running a business based on correct 
business management by implementing TQM so that the business organization that is being run can develop slowly with innovation and appropriate business strategies in accordance with market demand so as to get customer satisfaction who always demands quality products from MSMEs entrepreneurs.

Case solving 2: The MSMEs entrepreneurs who have tried to implement TQM must make the quality of bread products as an alternative for competitiveness with other MSMEs in the same industry. The MSMEs bread entrepreneurshave more focused on customer satisfaction by analyzing customer needs, always involving and empowering employees in decision making and problem solving, prioritizing leadership with solid teamwork, always improving employee training education in order they are updated about the development of the business they are engaged in, and continuously carry out improvements in all aspects of MSMEs.

\section{Good Practices If MSMEs Entrepreneurs Implement the TQM}

MSMEs is one of the pillars of the Indonesian economy which is created from the middle-down class society which can supports the economy of the families of the entrepreneurs greatly and can strengthen the economy of the Indonesian. Through MSMEs, new businesses can be created that can reduce unemployment and there are hopes that MSMEs can create entrepreneurs who are able to produce products by traditional characteristics with national or international quality without leaving the local wisdom. Local wisdom is a characteristic of MSMEsentrepreneurs must be able to innovate with the times in producing the new product, such as recreating traditional Sasak traditional snacks with cake innovations so that its able to compete in the market segment of the millennials people who control the current global market growth. This can be realized if MSMEs entrepreneurs want to move and implement the total quality management in their MSMEs operational activities because there are several good practices if TQM is applied by MSMEs entrepreneurs including:

1. MSMEs entrepreneurs automatically change their mindset in doing business and prioritize customer satisfaction as an alternative to increase competitiveness that can bring profit;

2. Making customers as top priority in order focus on providing product quality, innovation, marketing, service, and competitive prices;

3. Always empower the employees with clear delegations of duties and responsibilities by providing rewards and punishments;

4. The MSMEs leaders are able to become managers who implement the teamwork and able to become visionary leaders with bright ideas in developing the business;

5. Decision making based on data and facts is not based on feeling;

6. Providing the employees opportunities for improved education and training to enable them become innovators, initiative takers, creative problem solvers and more productive, effective and efficient in completing their work;
7. Always take continuous improvement actions in the management, production and marketing of MSMEs.

\section{Lessons Learned If TQM is Applied to MSMEs}

The lessons learned if TQM applied to MSMEs are leaders or owners of MSMEs capable of being visionary leaders who are able to analyze the challenges and opportunities that will be faced based on the influence of the internal and external environment that exist within the MSMEs. In addition, a visionary leader is also capable of being a manager who can motivate employees and become a leader who prioritizes teamwork, focusing on customer satisfaction, providing the best service for a wider market coverage towards a competitive advantage.

From the discussion above it can be seen that good practices and the lessons learned if Total Quality Management is applied to MSMEs based on Cross Case Study are 25 MSMEs entrepreneurs who have not implemented TQM face more problems and tend to face the same problems so that the bread business is stagnant and does not increase. In fact, every day there is a reduction in raw materials in production activities due to the large number of bread business entrepreneurs who come from outside Babakan village. From the MSMEs entrepreneur who has tried to implement TQM in his business operations, within 2 years has been able to produce various variants of bread, donuts, brownies, pastries, cakes based on consumer tastes at competitive prices, opening the outlets with online marketing systems through social media such as Instagram, Facebook, WhatsApp, even collaborating with unicorn and decacorn companies such as gojek and grabs so that the marketing digitization is maximized.

\section{CONCLUSION}

In practice, there are still many MSMEs bread entrepreneurs who have not implemented TQM in their business activities. The main reason is that most of these MSMEs bread entrepreneurs do not understand about TQM and do not even know what TQM is and how to implement it. This is because the level of education, age and intention in running a bread business are just continuing the business from the parents, without realizing that the business world continues to develop which requires to update the business knowledge including implementing of TQM. The implementation of TQM is no longer an option but has become an obligation so that MSMEs bread entrepreneurs will be able to resolve and eliminate business problems by always making continuous improvements that focus on customers and making quality as the main goal in running the business in order to be able to develop and survive in business competition.

\section{REFERENCES}

[1] Gaspersz, Vincent. "Total Quality Management: Untuk Praktisi Bisnis \& Industri." Bandung: Vincristo Publication (2011).

[2] Tjiptono, Fandy, and Anastasia Diana. "Total Quality Management Edisi Revisi." Yogyakarta: Andi (2003).

[3] Akhyar, Yundri. "Total Quality Management (Manajemen Mutu Terpadu)." Potensia: Jurnal Kependidikan Islam 13.1 (2014): 120.

[4] Dwiningsih, Sri. "Penerapan Activity Based Costing System dalam penentuan Harga Pokok Produksi pada Industri Roti 
Cempaka Mulia." JAMIN: Jurnal Aplikasi Manajemen dan Inovasi Bisnis 1.1 (2018): 38-48.

[5] Purba, Sahala. "Pengaruh Akuntansi Pertanggungjawaban Sebagai Alat Bantu Bagi Manajemen Dalam Menunjang Efektivitas Pengendalian Biaya pada PTPN III Medan." Jurnal Ilmiah Methonomi 2.1 (2016).

[6] Sumarsan, T. (2013). SistemPengendalianManajemen: Konsep, Aplikasi, dan Pengukuran Kinerja. In PT. Indeks. Jakarta Barat.

[7] Aziza, Nurul, Dirvi Surya Abbas, and M. Ak SE. Akuntansi Biaya: Konsep Dasar dan Manajemen. Mirra Buana Media, 2020.

[8] Krajewski, L. J., Ritzman, L. P., \& Malhotra, M. K. Operations management. Pearson, (2013).

[9] Creswell, John W. "Research design: pendekatan metode kualitatif, kuantitatif, dan campuran." Yogyakarta: Pustaka Pelajar (2016): 5.

[10] Denzin, Norman K., and Yvonna S. Lincoln. "Handbook of Qualitative Research, terjemahan Dariyatno, at. all." Yogyakarta: Pustaka Pelajar (2009). 